\section{Fibre Bragg Grating SENSOR SyStem for TEMPERATURE APPLICATION}

Suzairi Dauda,b*, Ahmad Fakhrurrazi Ahmad Noordena

aLaser Center, Ibnu Sina Institute for Scientific \& Industrial Research, Universiti Teknologi Malaysia, 81310 UTM Johor Bahru, Johor, Malaysia

bDepartment of Physics, Faculty of Science, Universiti Teknologi Malaysia, 81310 UTM Johor Bahru, Johor, Malaysia
Article history

Received

15 August 2015

Received in revised form

15 November 2015

Accepted

30 December 2015

*Corresponding author suzairidaud@utm.my
Graphical abstract

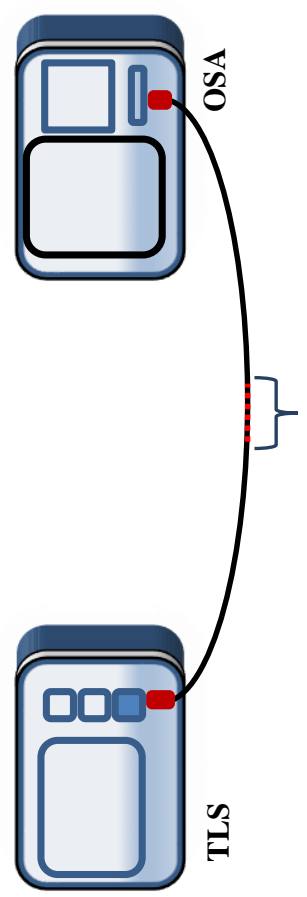

\section{Abstract}

A practical pass-through type fibre Bragg grating (FBG) temperature sensor system have been designed and experimentally investigated. The performance of FBG was evaluated with the varying of focusing elements in harsh environments, under direct sunlight. The sensor head of FBG was designed to be focused with convex and hand lens. Results shows that the Bragg wavelength shift, $\Delta \lambda_{B}$ increase proportionally with the temperature for both systems. The sensitivities of FBG were recorded to be 0.0107 and $0.0122 \mathrm{~nm}^{\circ} \mathrm{C}^{-1}$ for the system where convex and hand lens applied to the FBG's sensor head respectively.

Keywords: Fibre Bragg grating, temperature sensor, Bragg wavelength shift, focusing element

\begin{abstract}
Abstrak
Satu sistem pengesan suhu gentian parutan Bragg (FBG) telah direka dan diuji. Prestasi FBG dinilai dengan memberi tumpuan kepada unsur-unsur alam sekitaran dan di bawah pancaran cahaya matahari secara terbuka. Sistem pengesan FBG telah direka untuk memberi ditumpukan dengan kanta cembung dan kanta tangan. Keputusan menunjukkan bahawa perubahan panjang gelombang Bragg, $\Delta \lambda_{B}$ meningkat berkadaran dengan suhu bagi kedua-dua sistem. Kepekaan FBG dicatatkan sebanyak 0.0107 dan $0.0122 \mathrm{~nm}^{\circ} \mathrm{C}^{-1}$ untuk sistem di mana kanta cembung dan kanta tangan digunakan.

Kata kunci: Gentian parutan Bragg, pengesan suhu, perubahan panjang gelombang Bragg, elemen pemfokus
\end{abstract}

(c) 2016 Penerbit UTM Press. All rights reserved

\subsection{INTRODUCTION}

Fibre optic sensors emerged as modern device in sensing and communication technologies. Due to its unique advantages, FBG become the best fibre optic temperature sensor device as compared with others [1]. FBG technology was first developed by Hill et al. in 1978 [2]. It is based on the principle of Bragg reflection and can be used in measuring small changes in temperature and strain accurately [3].

Bragg wavelength changed corresponds with any small changes of strain, temperature, and/or wavelength of the Bragg grating. Parameter characteristics of lightwaves including amplitude, phase, and polarization will changed with external field changes [4] with the influence of light propagation in the fibre. The reflected light affected by the changes of wavelength, strain, and/or temperature applied onto the gratings. In this paper, the performance/sensitivity of FBG was tested in harsh environment, where the sensor head of the FBG exposed to sunlight will be measured directly with the existing of convex and hand lens. It will examine the 
reaction of FBG's sensor head where the temperature is addressed directly towards it.

\subsection{THEORY}

When an optical waves pass through an FBG, it will partially transmitted and reflected. Certain directions might be observed where wavelets created at each plane were in phase. A resonant condition is satisfied if these directions correspond to a mode of fibre caused the optical waves that partially reflected constructively interfere with each other only for a specific wavelength called 'Bragg wavelength' [5]. Hence, in a broadband source, only a narrow spectrum at Bragg wavelength was reflected and the rest will be transmitted through the FBG.

Theoretically, the Bragg wavelength of an FBG is given by the equation:

$\lambda_{B}=2 n_{\text {eff }} \Lambda$

where $n_{\text {eff }}$ is the effective refractive index and $\Lambda$ is the grating period of the fibre core.

The change in Bragg wavelength, $\Delta \lambda_{B}$ upon strain, temperature, and wavelength changes [6] can be expressed as:

$\Delta \lambda_{B}=2\left(\Lambda \frac{\delta n_{\text {eff }}}{\delta L}+n_{\text {eff }} \frac{\delta \Lambda}{\delta L}\right) \Delta L+2\left(\Lambda \frac{\delta n_{\text {eff }}}{\delta T}+n_{\text {eff }} \frac{\delta \Lambda}{\delta T}\right) \Delta T+$

$2\left(\Lambda \frac{\delta n_{\text {eff }}}{\delta \lambda}+n_{\text {eff }} \frac{\delta \Lambda}{\delta \lambda}\right) \Delta \lambda$

where $\Delta L$ is the change in length, $\Delta T$ is the change in temperature, and $\Delta \lambda$ is the change in wavelength.

Practically, the variation of refractive index due to the changes in wavelength is negligible [7]. The periodic spacing of the index modulations in fibre is unaffected by the wavelength change. By neglecting the wavelength effects, Eq. (2) can be rewritten as:

$\Delta \lambda_{B}=2\left(\Lambda \frac{\delta n_{e f f}}{\delta L}+n_{e f f} \frac{\delta \Lambda}{\delta L}\right) \Delta L+2\left(\Lambda \frac{\delta n_{e f f}}{\delta T}+n_{\text {eff }} \frac{\delta \Lambda}{\delta T}\right) \Delta T$

Any changes in physical spacing between successive indexes modulations will caused shift in Bragg wavelength. The strain-optic effect will induce changes in refractive index, thus causing shift in Bragg wavelength [8].

Thermal expansion or contraction changed the period of grating will affect the FBG optical response [9]. Thus, the Bragg wavelength, $\lambda_{B}$ and the effective refractive index, $n_{\text {eff }}$ are temperature dependent (thermo-optic effect). Therefore, the changes in Bragg wavelength for a given changed in temperature is given as:

$\Delta \lambda_{B}=\lambda_{B}(\varepsilon+\alpha) \Delta T$

where $\Delta \lambda_{B}$ is the Bragg wavelength change, $\lambda_{B}$ is the Bragg wavelength, $\varepsilon$ is the thermo-optic coefficient $(\varepsilon$ $\left.=0.213,8.60 \times 10^{-6}{ }^{\circ} \mathrm{C}^{-1}\right), \alpha$ is the thermal-expansion coefficient $\left(\alpha=0.55 \times 10^{-6}{ }^{\circ} \mathrm{C}^{-1}\right)$ and $\Delta T$ is the temperature change (in ${ }^{\circ} \mathrm{C}$ ) [11].

\subsection{EXPERIMENTAL SET-UP}

An optical FBG sensor was choosed. The FBG was connected with tunable laser source (TLS) and optical spectrum analyzer (OSA) through a single-mode optical fibre optic cable. Broadband light source from TLS was launched into the fibre core and transmitted through the FBG and fibre optics cable. As the broadband light propagates through it, the light source with its wavelength matched to the Bragg condition will be reflected, while the rest will be transmitted through the FBG. These induced a significant power dip at the Bragg wavelength.

Figure 1 shows the schematic diagram of the experimental set-up for measuring the transmission spectrum of the FBG. It is important to ensure that the connections are well connected. The spectra transmitted will be measured via the OSA and will be analyzed based on the Bragg wavelength shift and power dip.

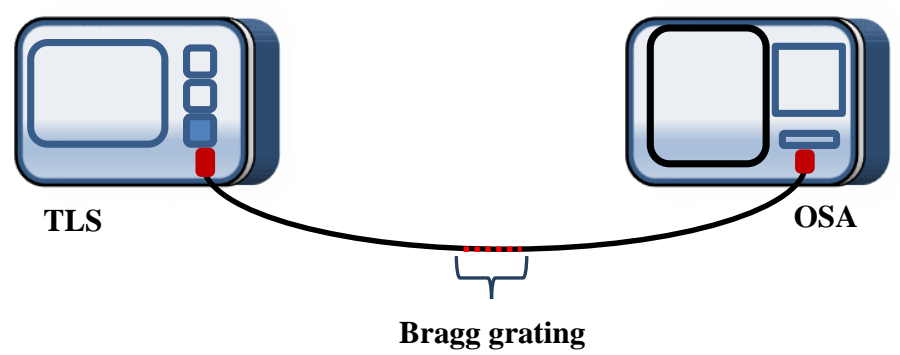

Figure 1 Schematic diagram of the experimental set-up for transmission spectrum measurements

\subsection{RESULTS AND DISCUSSION}

The experimental set-up to measure the sensitivity of FBG were prepared and placed at an open area. Broadband laser source was launched into the fibre core and the spectrum of FBG was measured via the OSA. Figure 2 shows the transmission spectrum of the FBG sensor at room temperature.

The Bragg wavelength changed with external temperature were observed. The perturbations of gratings results a shift in Bragg wavelength. As the outdoor temperature changes due to the environmental conditions, thermal expansion in the grating occurred caused the effective refractive index, $n_{\text {eff }}$ of FBG changed. This cause a variation in FBG wavelength, $\Delta \lambda_{B}$

Theoretical analysis of the performance of FBG was calculated based on Eq. (4). Figure 3 shows the comparison graph of Bragg wavelength shift, $\Delta \lambda_{B}$ against outdoor temperature for the transmission spectrum and theoretical analysis. Results show the linearity of FBG sensing system. There is a good correlation between temperature changes and Bragg wavelength shift obtained from the experiments done. A linear response observed 
between the temperature changed and Bragg wavelength shift throughout the measured region.

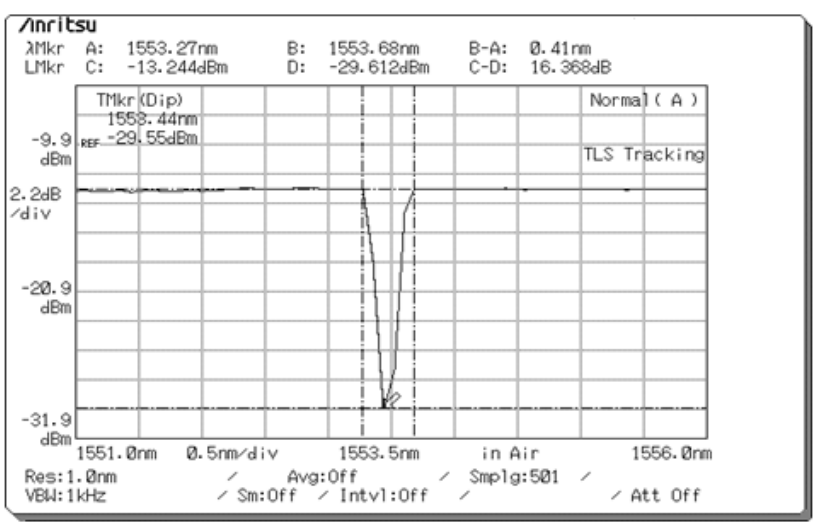

Figure 2 Transmission spectrum of FBG at room temperature

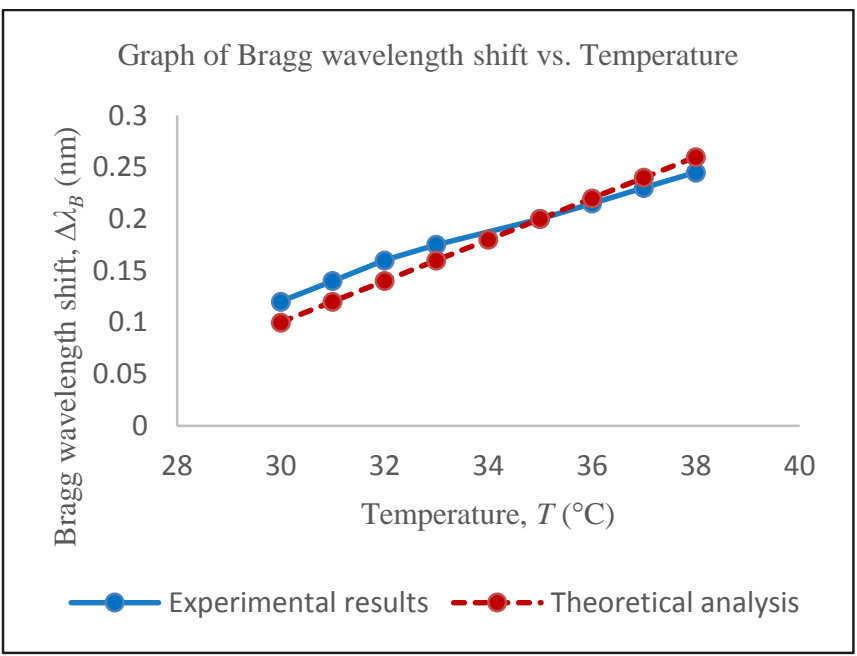

Figure 3 Comparison of the experimental results and theoretical analysis

The sensitivity of FBG measured with present of focusing elements (convex and hand lens). Figure 4 shows the graph of Bragg wavelength shift against temperature for the FBG sensor head focused with convex and hand lens respectively. The slope or gradient of graph determined the sensitivity of FBG. The sensitivity of FBG which focused with convex and hand lens were calculated to be 0.0107 and 0.0122 $n m^{\circ} \mathrm{C}^{-1}$ respectively. The sensitivity of FBG sensor head focused with hand lens is higher than the one focused with convex lens. It is conclude that the types of focusing element affect the performance of FBG.
Graph of Bragg wavelength shift vs. Temperature

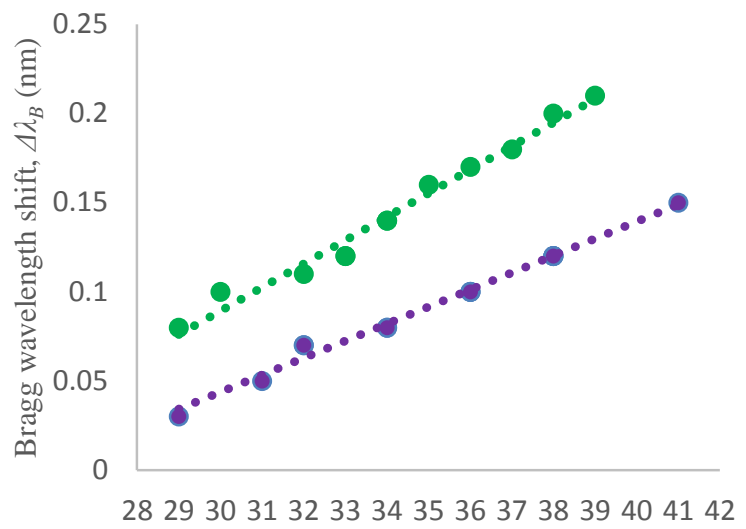

Temperature, $T\left({ }^{\circ} \mathrm{C}\right)$

- FBG sensor head focussed with convex lens

FBG sensor head focussed with hand lens

Figure 4 Sensitivity measurements of FBG focused with convex and hand lens

\subsection{CONCLUSION}

The sensitivity of FBG for the temperature sensor system has been designed, developed, and its performance has been tested theoretically and experimentally. An excellent linear response observed between the temperature changed and Bragg wavelength shift, $\Delta \lambda_{B}$ throughout the outdoor temperature range from 28 to $41{ }^{\circ} \mathrm{C}$ respectively. With the capability of the linear response, the FBG sensor can be used for outdoor temperature sensing.

\section{Acknowledgement}

Authors would like to thank Laser Center, Ibnu Sina Institute for Scientific \& Industrial Research, Universiti Teknologi Malaysia and Ministry of Higher Education Malaysia for the support in research facilities. This research work has supported by UTM's Potential Academic Staff vot. $01 \mathrm{~K} 80$ and Ministry of Higher Education Malaysia.

\section{References}

[1] Neil, J. G. 1999. Development of Temperature Compensated Fiber Optic Strain Sensors Based on Fiber Bragg Gratings. University of Toronto, Institute for Aerospace Studies.

[2] Hill, K. O., Fujii, Y., Johnson, D. C. and Kawasaki, B. S. 1978. Photosensitivity in Optical Fiber Waveguides: Application to Reflection Filter Fabrication. Applied Physics Letter. 32(10): 647-649. 
[3] Daud, S., Jalil, M. A., Najmee, S., Saktioto, Ali, J. and Yupapin, P. P. 2011. Development of FBG Sensing System for Outdoor Temperature Environment. Procedia Engineering. 8: 386-392.

[4] Daud, S., Ueamanapong, S., Srithanachai, I., Poyai, A., Niemcharoen, S., Ali, J. and Yupapin, P. P. 2012. Particle Accelerator Using Optical Tweezers for Photodetector Performance Improvement. IEEE Transaction on Nanotechnology. 11 (6): 1087-1092.

[5] Bawei, Z. and Mojtaba, K. 2007. High-Temperature Resistance Fibre Bragg Grating Temperature Sensor Fabrication. IEEE Sensors Journal. 7: 586-591.

[6] Xia, M., Jiang, M., Sui, Q. M. and Lei, J. 2015. Theoretical and Experimental Analysis of Interaction from Acoustic Emission on Fiber Bragg Grating. Optik. 126: $1150-1155$.

[7] Othonos, A. and Kalli, K. 1999. Fiber Bragg Grating; Fundamentals and Applications in Telecommunications and Sensing. Applied Optics. 45(8).
[8] Hee, C. and Lee, J. 2011. Characteristics of a Fiber Bragg Grating Temperature Sensor Using the Thermal Strain of an External Tube. Journal of the Korean Physical Society. 59(5): 3188-3191.

[9] Patrick, H. J., Williams, G. M., Kersey, A. D. and Pedrazzani, J. R. 1996. Hybrid Fiber Bragg Grating: Long Period Fiber Grating Sensor for Strain/Temperature Discrimination. IEEE Photonics Technology Letters. 8(9): 1223.

[10] Jung, J., Nam, H., Lee, B., Byun, J. O. and Kim, N. S. 1999. Fiber Bragg Grating Temperature Sensor with Controllable Sensitivity. Applied Optics. 38(13).

[11] Zhang, B. and Kahrizi, M. 2007. High-Temperature Resistance Fiber Bragg Grating Temperature Sensor Fabrication. IEEE Sensors Journal. 7(4). 